\title{
An Assessment of the Written Performance of the Sudanese EFL University Learners: A Communicative Approach to Writing
}

\author{
Ali Ahmed Osman Zakaria ${ }^{1}$ \& Abdel Rahim Hamid Mugaddam², \\ ${ }^{1}$ Department of English, Kassala University, Kassala, Sudan \\ ${ }^{2}$ Institute of African \& Asian Studies, University of Khartoum, Khartoum, Sudan \\ *Corresponding author: Institute of African \& Asian Studies, University of Khartoum, P.O. Box 321, Postal code \\ 11115, Eljamma Street, Khartoum, Sudan. E-mail: sudan_98@hotmail.com Tel: 249-913-646-644
}

Received: August 20, 2013

Accepted: September 20, $2013 \quad$ Online Published: October 21, 2013

doi:10.5430/wjel.v3n4p1

URL: http://dx.doi.org/10.5430/wjel.v3n4p1

\begin{abstract}
This study investigates the written performance of the Sudanese EFL students at tertiary level. The study aims to assess the written texts produced by the students in order to find out how successful they are in their use of writing as a mechanism through which meaning is communicated. To achieve this aim, the researchers employed the analytic descriptive method. The subjects of the study consist of 65 Sudanese EFL teachers working at some Sudanese universities and 240 fourth level students who are taking English as a major course in five universities. Three tools were used for data collection: writing test, two questionnaires (one for the teachers and the other for the students) and an interview with the students. Analysis shows that Sudanese EFL students did cope with the different modes of writing. They were unable to make use of writing strategies such as pre-activities and organization. Furthermore, the study suggests that the students made no use of teachers and peers feedback while writing. Findings also revealed a total lack of awareness of cohesive devices on the part of the students. That is, they produced disconnected sentences and incoherent paragraphs. The study concludes that the students' language problems, lack of organizational skills, and inability to meet the audience expectations were among the factors that would make them produce less informative written texts.
\end{abstract}

Keywords: communicative writing; audience awareness; organizational skills; instructive feedback

\section{Introduction}

Writing is a complex cognitive process which, as stated by Hazel (2005), does not arise out of a vacuum: there is always a process involved. Such a process requires students to have linguistic and writing skills which enable them to produce a wide range of texts for a variety of purposes across a broad class of social contexts (Deane et al. 2008). Kellogg (2008) points out that learning how to write a coherent, effective text is difficult and protracted achievement of cognitive development. To write an extended text at an advanced level involves not just the language system. It poses significant challenges to our cognitive systems for memory and thinking. Elbow (1998) reports that writing calls on two different skills that usually conflict with each other. That is, writing calls on the ability to create words and ideas, but it also calls on the ability to criticize them in order to decide which ones to use. When one begins to realize how writing calls on the opposite skills of creativity and critical thinking, one gets a better understanding of the difficulty involved.

Sudanese EFL students do not appreciate the complexity associated with the process of writing. They fail to employ their cognitive abilities in order to create ideas for writing. The students do not have the ability to evaluate the information and ideas they gather and ultimately select the items which serve their writing purpose. This is why the writing produced by them is less informative. The main objective of this study is investigating the written performance of Sudanese EFL students at university level. To this end, we will focus specifically on students' writing habits to see if they have the ability to write texts that make sense from a communicative point of view. That is, we will try to find out if the students are able to develop a particular topic into a meaningful thought. Another aim the paper seeks is to identify the problems students face in writing and try to suggest remedial measures for them. 


\section{Background}

Writing, in the traditional approaches to language teaching and learning, was considered a secondary skill. Therefore, it received relatively little attention compared to speaking, reading, and listening. Leki, (1992), Matsuda, (2001, 2003); Silva, (1997), claim that the dominant teaching method during the 1950s put an undue focus on oral rather than written proficiency. Theories such as those incorporated in the audio-lingual method dominated the pedagogy of ESL classes especially in 1950s and early 1960s. So writing was not given much emphasis in the syllabus. Accordingly, little attention has been paid to the development of students' EFL writing abilities. Part of the problem, according to Camps (1994), lies in the fact that in many EFL contexts, such as in Spain, there is no solid tradition in the teaching of L1 writing skills, whose learning has been often left to the students themselves. Most of the syllabuses in the field of EFL/ESL are concerned with developing students' speaking, listening, and reading abilities, but not with writing. This is confirmed by Kress (1993), who states that the number of books on learning reading is vast; by contrast there are few books on learning how to write.

The situation did not remain as such for a long time. In the early 1960s, as reported by Fujieda (2006), large numbers of foreign students entered higher education in the U.S. At this stage, L1 composition instructors perceived major differences in writing between L1 and L2 learners. These differences rekindled interest in teaching writing to non-native speakers. Along with this, a consideration of pedagogical approaches to L2 learners developed. The differences in teaching writing between native and non-native speakers resulted in controversial issues. Writing teachers became critical of how to teach writing in English to ESL learners. Matsuda (1998, 1999, and 2003) argues that writing pedagogy is divided into L1 and L2 issues to draw a division between composition studies and L2 studies.

Since writing is a very important element in the continuum of proper literacy, it needs to be treated in such a way that enables students to better express their thoughts through the written form of language. Unless EFL/ESL teachers and experts appreciate the importance of writing, no progress will be achieved in this respect. Of course, the job of teachers and EFL/ESL experts is to consider this fact. Matsuda $(2001,2002)$ contends that writing should imply an advanced and extensive language technique. Learners need to be well-prepared so that they can deal with writing properly. Leki (1992) adds that learners are required to have fundamental knowledge to produce full composition with paragraphs.

Previous research has shown that EFL/ESL students experience serious difficulties in the composing process. One of these difficulties is how to produce a well-connected and coherent piece of writing. In order to help students understand the importance of producing a unified and solid piece of writing many researchers conducted studies in this respect. Abdellah (2000), for example, found that Sudanese university students were not able to make correct use of written discourse properties, which eventually reduces the overall writing quality. He adds that the average writing of student was characterized by a variety of coherence breaks such as misleading paragraph division and irrelevance. This result coincides with Olatejo's findings (2006), who found that Nigerian ESL students were unable to use cohesive devices. This made their writing appear incomprehensible. This was because they were not able to use cohesive devices in writing despite the instruction they received on English for six years. Olatejo went further suggesting that the students were not exposed to the essentials of the English language. As such, they were not to blame for their failure to use cohesive devices properly. To overcome this problem, we suggest explicit instruction on the use of cohesive devices in writing.

Studies also reveal that some students avoid the use of cohesive devices in writing and others overuse them. This makes their writing appear awkward. Part of the reasons behind the difficulties students face in this respect resides in the teachers' ignorance of the importance of coherence and cohesion. Therefore, the studies recommend that teachers should first appreciate the importance of coherence and cohesion and then endeavor to raise students' awareness of them when writing in English.

Adopting strategies necessary for producing appropriate written texts is one of the challenges that EFL students face. Success in adopting the right writing strategies is an important step towards producing texts which are communicative in nature. So, instruction in writing strategies needs to address these challenges so that the students can succeed in producing effective texts. El Abed (1991) claims that there are no significant differences in writing quantity and quality between students who write with prewriting activities and those who do not. However, it is obvious that adopting such activities can result in better writing. Zhang and Vukelich (1998) claimed that students who write with prewriting activities perform better than those who do not use them. Pishghadam and Ghanizadeh (2006) investigate the impact of concept mapping as a prewriting activity on Iranian EFL learners' writing ability. Results revealed that concept mapping enhanced students' writing ability. The students who engaged in prewriting 
activities proved to be better in L2 writing. Sasaki (2000) reports that expert writers always consider prewriting activities. Sasaki argues that after making their plans, experts did not stop and think as frequently as the novices did. Teachers of English should consider such findings in attempting to have thoughtful insights into the nature of the difficulties students face in writing.

\section{Materials and Methods}

\subsection{Participants}

The participants in this study include 65 EFL teachers and 240 students at five Sudanese universities. The students belong to Kassala University, Gadaref University, the Red Sea University, Omdurman Islamic University and Omdurman Ahlia University. Teachers have been chosen based on the fact that they play an important role in promoting and developing students' writing skills in particular and the learning process in general. Students are chosen due to the nature of the research questions and hypotheses which address their communicative competence in writing.

\subsection{Instruments}

The data of this study were collected through a test, questionnaires, and an interview. Test, questionnaire and interview were designed for the students chosen as a sample population, while teachers will be asked to respond to a special questionnaire (teachers' questionnaires).

\subsection{Questionnaires}

\subsubsection{Teachers' Questionnaire}

The main objective of this questionnaire is to explore the teachers' appraisal of the students' writing in English. The questionnaire also seeks to find out the teachers' evaluative perception of the factors that influence students' written discourse. The researchers designed a 42 -items questionnaire in the format of a five point scale which is divided into six sections (see appendix 1). The first section comprises the items 1-7, inspecting teachers' assessment and evaluation of the students' writing. The second section consists of the items 8-12 which deal with the influence of motivation on students writing. The third section involves the items 13-19 which investigate the role of instructors in developing students' performance in writing. The fourth section includes the items 20-26 dealing with the teachers' view on the writing materials prepared for EFL in the Sudanese universities. The fifth section comprises items from 27-33, is about the influence of the writing environment on the students' written discourse. The final section, which includes the items 34-42, explores the role of teachers and peers feedback in developing students' communicative competence.

\subsubsection{Students' Questionnaire}

Students' questionnaire investigates the participants' perception and evaluation of their own capacities in writing. It consists of 37 questions which are divided into six categories (see appendix 2). The first category comprises items from 1 to 8 . This section explores the participants' judgment of their own writing performance. The second category includes the items from 9 to 13. It deals with students' awareness of the target audience. The third category involves the items from 14 to 19 investigating the subjects' writing motivation. The fourth category comprises the items from 20-26. It is about students' evaluation of the writing strategies they adopt. The fifth category consists of the items from 27-32 addressing students appraisal of their organizational skills. The last category comprises the items from 33 to 37 which investigate the subjects' evaluation of the feedback they receive from teachers during writing.

\subsection{Interviews}

The rationale behind the interview conducted with some of the participants is to reveal some of aspects of the students' written performance which could not be obtained through questionnaires. Twenty students were chosen for the interview. They were asked about the potential audience, writing activities, writing strategies, organization skills, and teachers' feedback (See appendix 3).

\subsection{The Test}

The students were asked to write one composition on a certain topic. The task was done during a regular university lecture. This is meant to remove any sort of anxiety among the subjects. The participants were given one hour to accomplish the task. The topic was associated with the sort of activities in which students were engaged during their daily life. Such topics may enable the students to write freely and comfortably because they address things which are meaningful to them. Raimes (1983) argues that when a meaningful writing task is assigned to the students, they will 
put more thought and efforts into a piece of writing that communicate their ideas and opinions to the reader. The following topics were given for students to choose to write on:

1- $\quad$ "Many people leave their country. Why?" Give illustrations and reasons to support your answer.

2- $\quad$ "My past, present and future."

3- $\quad$ "My future wife/husband."

4- $\quad$ "How do you spend your evenings?"

5- $\quad$ "Some people state that women should not work". Are you for or against this statement?

The reason behind offering a variety of topics is to enable the participants to deal with issues that suit their interests, and thus can write on fluently. The test was designed to assess students' ability to use writing for communication. That is, it tests students' ability to convey their thoughts to the potential audience.

\section{Results and Discussion}

\subsection{Students' Writing Proficiency}

The following table shows teachers' opinion on the students' writing proficiency

Table 1: Teachers' Evaluation of the Students' Writing Proficiency

\begin{tabular}{|c|c|c|c|c|c|c|c|}
\hline No & Item & $\begin{array}{l}\text { Strongly } \\
\text { agree }\end{array}$ & Agree & $\begin{array}{l}\text { No } \\
\text { opinion }\end{array}$ & Disagree & $\begin{array}{l}\text { Strongly } \\
\text { disagree }\end{array}$ & Median \\
\hline 1 & $\begin{array}{l}\text { Most of the Sudanese EFL students are } \\
\text { unaware of the fact that each type of writing } \\
\text { has its own unique set of rhetorical choices. }\end{array}$ & $\begin{array}{l}27.7 \% \\
18\end{array}$ & $\begin{array}{l}49.2 \% \\
32\end{array}$ & $\begin{array}{l}10.8 \% \\
7\end{array}$ & $\begin{array}{l}12.3 \% \\
8\end{array}$ & . & 2 \\
\hline 2 & $\begin{array}{l}\text { Sudanese EFL students fail to appreciate the } \\
\text { social context in which discourse is used by } \\
\text { users of the target language. }\end{array}$ & $\begin{array}{l}21.5 \% \\
14\end{array}$ & $\begin{array}{l}49.2 \% \\
32\end{array}$ & $\begin{array}{l}16.9 \% \\
11\end{array}$ & $\begin{array}{l}10.8 \% \\
7\end{array}$ & $\begin{array}{l}1.5 \% \\
1\end{array}$ & 2 \\
\hline 3 & $\begin{array}{l}\text { Most of the Sudanese EFL students lack the } \\
\text { ability to plan their writing with the audience } \\
\text { in their minds. }\end{array}$ & $\begin{array}{l}29.2 \% \\
19\end{array}$ & $\begin{array}{l}49.2 \% \\
32\end{array}$ & $\begin{array}{l}15.4 \% \\
10\end{array}$ & $\begin{array}{l}6.2 \% \\
4\end{array}$ & . & 2 \\
\hline 4 & $\begin{array}{l}\text { The majority of the Sudanese EFL students } \\
\text { are unable to develop evaluation and } \\
\text { reformulation strategies as part of their } \\
\text { writing process. }\end{array}$ & $33.8 \%$ & $36.9 \%$ & $18.5 \%$ & $10.8 \%$ & . & 2 \\
\hline 5 & $\begin{array}{l}\text { Sudanese EFL students' poor linguistic } \\
\text { knowledge makes them unable to develop a } \\
\text { particular topic into a unified and coherent } \\
\text { text. }\end{array}$ & $33.8 \%$ & $36.9 \%$ & $7.7 \%$ & $20.0 \%$ & $1.5 \%$ & 2 \\
\hline 6 & $\begin{array}{l}\text { Sudanese EFL students ignore the role of } \\
\text { cohesion in achieving the link between ideas. }\end{array}$ & $\begin{array}{l}23.1 \% \\
15\end{array}$ & $\begin{array}{l}38.5 \% \\
25\end{array}$ & $\begin{array}{l}18.5 \% \\
12\end{array}$ & $\begin{array}{l}16.9 \% \\
11\end{array}$ & $\begin{array}{l}3.1 \% \\
2\end{array}$ & 2 \\
\hline 7 & $\begin{array}{l}\text { The stress of trying to write perfectly } \\
\text { negatively influences students' writing. }\end{array}$ & $\begin{array}{l}20.0 \% \\
13\end{array}$ & $\begin{array}{l}36.9 \% \\
24\end{array}$ & $\begin{array}{l}26.2 \% \\
17\end{array}$ & $\begin{array}{l}15.4 \% \\
10\end{array}$ & $\begin{array}{l}1.5 \% \\
1\end{array}$ & 2 \\
\hline
\end{tabular}

Analysis of the teachers' questionnaires reveals that most of the Sudanese EFL students were unable to distinguish between different modes of written discourse. The analysis also shows that the students were not aware of the readers while they are planning for the writing task. That is, they were unable to make assumptions regarding what the readers already know about the topic (what they take for granted) or what they wish to find new. But the students stated that they knew the type of writing and the language content required for producing texts with different genres. The results obtained from analyzing the actual writing of the students support the teachers' view that the students had poor writing proficiency and were not able to make the right rhetorical choices meeting the reader's expectations. This made the students fails to produce the sort of texts that can stimulate the readers and grab their attention. However, the data obtained from the target teachers and the writing of the students support the hypothesis that the students produced incomplete and non- informative texts. 


\subsection{Students' Writing Motivation}

Table 2 shows students' motivation for writing.

Table 2: Teachers' Assessment of Students' Writing Motivation

\begin{tabular}{|c|c|c|c|c|c|c|c|}
\hline No & Item & $\begin{array}{l}\text { Strongly } \\
\text { agree }\end{array}$ & Agree & $\begin{array}{l}\text { No } \\
\text { opinion }\end{array}$ & Disagree & $\begin{array}{l}\text { Strongly } \\
\text { disagree }\end{array}$ & Median \\
\hline 8 & $\begin{array}{l}\text { Sudanese EFL writers never seek help from } \\
\text { their teachers or their peers when generating } \\
\text { and developing ideas relevant to their topics. }\end{array}$ & $\begin{array}{l}18.5 \% \\
12\end{array}$ & $\begin{array}{l}35.4 \% \\
23\end{array}$ & $\begin{array}{l}10.8 \% \\
7\end{array}$ & $32.3 \%$ & $\begin{array}{l}3.1 \% \\
2\end{array}$ & 2 \\
\hline 9 & $\begin{array}{l}\text { Most of the Sudanese EFL writers are } \\
\text { reluctant in their writing assuming that it is a } \\
\text { tiresome and complicated process. }\end{array}$ & $\begin{array}{l}20.0 \% \\
13\end{array}$ & $\begin{array}{l}52.3 \% \\
34\end{array}$ & $\begin{array}{l}10.8 \% \\
7\end{array}$ & $\begin{array}{l}16.9 \% \\
11\end{array}$ & . & 2 \\
\hline 10 & $\begin{array}{l}\text { Sudanese EFL writers never exert themselves } \\
\text { to search for opportunities to engage in a } \\
\text { productive act of written communication. }\end{array}$ & $\begin{array}{l}26.2 \% \\
17\end{array}$ & $\begin{array}{l}43.1 \% \\
28\end{array}$ & $\begin{array}{l}13.3 \% \\
9\end{array}$ & $\begin{array}{l}12.3 \% \\
8\end{array}$ & $\begin{array}{l}4.6 \% \\
3\end{array}$ & 2 \\
\hline 11 & $\begin{array}{l}\text { Most of the Sudanese EFL writers never } \\
\text { attempt to study authentic materials in order to } \\
\text { observe how written discourse is structured by } \\
\text { users of the target language. }\end{array}$ & $\begin{array}{l}26.2 \% \\
17\end{array}$ & $\begin{array}{l}47.7 \% \\
31\end{array}$ & $6.2 \%$ & $\begin{array}{l}18.5 \% \\
12\end{array}$ & $\begin{array}{l}1.5 \% \\
1\end{array}$ & 2 \\
\hline 12 & $\begin{array}{l}\text { The nature of the materials used in EFL } \\
\text { writing courses does not encourage the } \\
\text { Sudanese EFL writers to get involved in a } \\
\text { fruitful act of writing. }\end{array}$ & $\begin{array}{l}27.7 \% \\
18\end{array}$ & $\begin{array}{l}35.4 \% \\
23\end{array}$ & $\begin{array}{l}13.8 \% \\
9\end{array}$ & $\begin{array}{l}20.0 \% \\
13\end{array}$ & $\begin{array}{l}3.1 \% \\
2\end{array}$ & 2 \\
\hline
\end{tabular}

Responses to the items in the table above show that Sudanese EFL students were not enthusiastic enough to benefit from the presence of their teachers or peers while they were performing writing tasks. This makes them miss the opportunity of evaluating and re-evaluating the ideas they develop when writing. The table also suggests that students were not committed to the writing tasks due to the negative stereotype they developed about writing. However, the students reported that they were committed to writing to the extent that they missed no chance to read authentic materials and write consistently to develop their writing skill. But by investigating the students' actual writing performance, we realized that this claim is not true. The writings we went through show no signs of development due to intensive reading and frequent writing practices.

4.3 EFL Writing Syllabus

Table 3 shows the role of writing materials in the development or deterioration of students' writing abilities.

Table 3: Teachers' Evaluation of the Writing Materials

\begin{tabular}{|c|c|c|c|c|c|c|c|}
\hline No & Item & $\begin{array}{l}\text { Strongly } \\
\text { agree }\end{array}$ & Agree & $\begin{array}{l}\text { No } \\
\text { opinion }\end{array}$ & Disagree & $\begin{array}{l}\text { Strongly } \\
\text { disagree }\end{array}$ & Median \\
\hline \multirow[t]{2}{*}{20} & \multirow{2}{*}{$\begin{array}{l}\text { EFL writing courses do not guide students to } \\
\text { visualize how a piece of writing establishes its } \\
\text { communicative purpose. }\end{array}$} & $24.6 \%$ & $38.5 \%$ & $13.8 \%$ & $21.5 \%$ & $1.5 \%$ & 2 \\
\hline & & 16 & 25 & 9 & 14 & 1 & \\
\hline \multirow[t]{2}{*}{21} & \multirow{2}{*}{$\begin{array}{l}\text { The teaching of writing defines texts as a } \\
\text { regular arrangement of grammatical units and } \\
\text { sentences. }\end{array}$} & $9.2 \%$ & $46.2 \%$ & $9.2 \%$ & $32.3 \%$ & $3.1 \%$ & 2 \\
\hline & & 6 & 30 & 6 & 21 & 2 & \\
\hline \multirow[t]{2}{*}{22} & \multirow{2}{*}{$\begin{array}{l}\text { EFL writing courses should be based on the } \\
\text { activities that make students know what is } \\
\text { expected socially and culturally by users of the } \\
\text { target language. }\end{array}$} & $43.1 \%$ & $44.6 \%$ & $4.6 \%$ & $6.2 \%$ & - & 2 \\
\hline & & 28 & 29 & 3 & 4 & . & \\
\hline \multirow[t]{2}{*}{23} & \multirow{2}{*}{$\begin{array}{l}\text { EFL writing syllabus lack the sort of the } \\
\text { activities that raise students' genre awareness. }\end{array}$} & $27.7 \%$ & $49.2 \%$ & $7.7 \%$ & $12.3 \%$ & $3.1 \%$ & 2 \\
\hline & & 18 & 32 & 5 & 8 & 2 & \\
\hline
\end{tabular}




24
$\begin{aligned} & \text { The activities incorporated in the writing } \\ & \text { syllabus do not develop students' awareness of }\end{aligned}$
the English rhetorical modes of writing.

Table 3 shows that a vast majority of the teachers reported that the writing materials in most of the Sudanese universities were not based on the types of activities which equip the students with the social and cultural knowledge necessary for understanding written English. This confirms the hypothesis that the writing syllabus in most of the Sudanese universities did not meet students' writing needs.

\subsection{Writing Instructors}

The following table presents teachers' evaluation of the role of instructors in developing students' writing competence.

Table 4: Teachers' Opinion of the Role of Writing Instructors in Developing Students' Writing Abilities

\begin{tabular}{|c|c|c|c|c|c|c|c|}
\hline No & Item & $\begin{array}{l}\text { Strongly } \\
\text { agree }\end{array}$ & Agree & $\begin{array}{l}\text { No } \\
\text { opinion }\end{array}$ & Disagree & $\begin{array}{l}\text { Strongly } \\
\text { disagree }\end{array}$ & Median \\
\hline \multirow[t]{2}{*}{13} & $\begin{array}{l}\text { Instructors should help students access a } \\
\text { number of grammatical resources which }\end{array}$ & $58.5 \%$ & $40.0 \%$ & . & $1.5 \%$ & • & 1 \\
\hline & $\begin{array}{l}\text { could help them improve their writing } \\
\text { competence. }\end{array}$ & 38 & 26 & - & 1 & . & \\
\hline \multirow[t]{2}{*}{14} & Most of the Sudanese writing instructors & $23.1 \%$ & $46.2 \%$ & $13.8 \%$ & $16.9 \%$ & . & 2 \\
\hline & $\begin{array}{l}\text { contribute to the production of unified and } \\
\text { coherent texts. }\end{array}$ & 15 & 30 & 9 & 11 & . & \\
\hline \multirow[t]{2}{*}{15} & $\begin{array}{l}\text { Most of the teachers never exert } \\
\text { themselves to improve their understanding }\end{array}$ & $29.2 \%$ & $46.2 \%$ & $1.5 \%$ & $23.1 \%$ & - & 2 \\
\hline & of how to view students as writers. & 19 & 30 & 1 & 15 & - & \\
\hline \multirow[t]{2}{*}{16} & $\begin{array}{l}\text { Many of the Sudanese teachers do not } \\
\text { attempt to guide students towards a }\end{array}$ & $24.6 \%$ & $49.2 \%$ & $4.6 \%$ & $20.0 \%$ & 1.5 & 2 \\
\hline & $\begin{array}{l}\text { conscious awareness of how audience will } \\
\text { interpret their writing. }\end{array}$ & 16 & 32 & 3 & 13 & 1 & \\
\hline \multirow[t]{2}{*}{17} & $\begin{array}{l}\text { Teachers need to develop more serious } \\
\text { attitudes towards writing if they wish to }\end{array}$ & $53.8 \%$ & $41.5 \%$ & $3.1 \%$ & $1.5 \%$ & . & 1 \\
\hline & $\begin{array}{l}\text { raise students' awareness of the } \\
\text { communicative value of texts. }\end{array}$ & 35 & 27 & 2 & 1 & . & \\
\hline \multirow[t]{2}{*}{18} & $\begin{array}{l}\text { Writing instructors never encourage their } \\
\text { students to take writing as a means of }\end{array}$ & $20.0 \%$ & $27.7 \%$ & $13.8 \%$ & $38.5 \%$ & . & 3 \\
\hline & expressing meaning. & 13 & 18 & 9 & 25 & - & \\
\hline \multirow[t]{2}{*}{19} & $\begin{array}{l}\text { Teachers should encourage students to } \\
\text { focus on the whole text rather than on }\end{array}$ & $50.8 \%$ & $38.5 \%$ & $1.5 \%$ & $4.6 \%$ & $4.6 \%$ & 1 \\
\hline & $\begin{array}{l}\text { individual sentences while they are } \\
\text { writing. }\end{array}$ & 33 & 25 & 1 & 3 & 3 & \\
\hline
\end{tabular}

Analysis of Table 4 shows that most of the teachers surveyed emphasized the importance of designing writing tasks in a way that directly addresses learners' needs. This indicates that the teachers are expected to help improve students writing abilities by developing positive attitudes towards writing among the students. By doing so, teachers can help 
the students produce writing that could be interesting for readers.

\subsection{Students' Organizational Skills}

The students stated that they were unable to adopt different strategies during the writing process. This enability, according to the students' viewpoint, made them produce incoherent texts. This confirms Abdellah (2000) and Olatejo (2006) findings showing that the students they studied failed to use cohesive devices in writing coherent texts. The students' actual written performance in this study strongly supports this statement. We have spotted many instances of disconnected texts, misuse or total absence of cohesive devices. Table 5 bellow shows the students' inability to produce well organized and unified pieces of writing.

Table 5: Students' Scores in the Writing Test

\begin{tabular}{lll}
\hline Scoring range & Frequency & Percentage \\
\hline $90-100$ & - & - \\
$80-89$ & 4 & $1.7 \%$ \\
$70-79$ & 8 & $3.3 \%$ \\
$60-69$ & 12 & $5.0 \%$ \\
$50-59$ & 18 & $7.5 \%$ \\
$40-49$ & 28 & $11.7 \%$ \\
$30-39$ & 48 & $20.0 \%$ \\
Less than 30 & 122 & $50.8 \%$ \\
Total & 240 & $100.0 \%$ \\
\hline
\end{tabular}

The table shows that only $17.5 \%$ of the subjects wrote acceptable texts. This means that $82.5 \%$ of the students could not produce coherent and well organized texts. If we read this finding in line with teachers' reports on students writing ability, we will come to the conclusion that English major students at Sudanese university experience a serious problem in writing English texts. That is, the students' actual written performance is far from being coherent and well organized. The following extracts give a good example of the students' writing:

1- There are many people left their contrise for many reasons: They Suffering from. health - Education and civil war and poverty. They moved from growing countries to developing countries, they do not want to live in poverty and problems health, when they comp-lainng about their problems. There isn't answer or reponsed, All the responsibilities ignore them recurs.

2- Some people state that women should not work, I am do agree with theme because I believe that women they have no abilities to every work even if they have the ability to do it is not their responsibility, their responsibility is how to organise their houses.

3- For many reasons people can leave their countary although that is defcult for them but, as we know the development of the incom is the firstly important reson that guide people to leave their countary particular in the develop countary, that is most after they graduate from the university they think or know that the opportune to work inside their countary is lemeted or fixed, so that they decided to leave their countary.

4- ... Although all family work to justify their needs, women had an important role, because she helped her husband in the farm...

\subsection{Writing Environment}

The following table gives teachers' critical appraisal of the role played by writing environment in the development of the students' writing competence. 
Table 6: Teachers' Evaluation of the Role of Writing Environment in Developing Students Written Communicative Competence

\begin{tabular}{|c|c|c|c|c|c|c|c|}
\hline No & Item & $\begin{array}{l}\text { Strongly } \\
\text { agree }\end{array}$ & Agree & $\begin{array}{l}\text { No } \\
\text { opinion }\end{array}$ & Disagree & $\begin{array}{l}\text { Strongly } \\
\text { disagree }\end{array}$ & Median \\
\hline \multirow[t]{2}{*}{27} & $\begin{array}{l}\text { The environment in which writing is done in } \\
\text { most of the Sudanese universities does not }\end{array}$ & $26.2 \%$ & $55.4 \%$ & $9.2 \%$ & $7.7 \%$ & $1.5 \%$ & 2 \\
\hline & $\begin{array}{l}\text { reinforce the functional dimension of } \\
\text { communication. }\end{array}$ & 17 & 36 & 6 & 5 & 1 & \\
\hline \multirow[t]{2}{*}{28} & $\begin{array}{l}\text { Most of the writing is done at home as an } \\
\text { assignment which means students miss the }\end{array}$ & $41.5 \%$ & $46.2 \%$ & $3.1 \%$ & $7.7 \%$ & $1.5 \%$ & 2 \\
\hline & opportunity to exchange ideas with their peers. & 27 & 30 & 2 & 5 & 1 & \\
\hline \multirow[t]{2}{*}{29} & $\begin{array}{l}\text { Some students do not have the academic } \\
\text { advantage of teacher-students interaction }\end{array}$ & $55.4 \%$ & $41.5 \%$ & . & $1.5 \%$ & $1.5 \%$ & 1 \\
\hline & because of the size of the class. & 36 & 27 & . & 1 & 1 & \\
\hline \multirow[t]{2}{*}{30} & $\begin{array}{l}\text { Writing environment should be turned into a } \\
\text { dynamic scene of communication to help }\end{array}$ & $47.7 \%$ & $47.7 \%$ & $1.5 \%$ & $3.1 \%$ & . & 2 \\
\hline & $\begin{array}{l}\text { Sudanese EFL writers develop their written } \\
\text { communicative competence. }\end{array}$ & 31 & 31 & 1 & 2 & . & \\
\hline \multirow[t]{2}{*}{31} & $\begin{array}{l}\text { EFL writing environment should guide the } \\
\text { students to recognize the role of audience in }\end{array}$ & $41.5 \%$ & $47.7 \%$ & $7.7 \%$ & $3.1 \%$ & . & 2 \\
\hline & the process of writing. & 27 & 31 & 5 & 2 & . & \\
\hline \multirow[t]{2}{*}{32} & Teachers need to play the role of the audience & $35.4 \%$ & $49.2 \%$ & $4.6 \%$ & $9.2 \%$ & $1.5 \%$ & 2 \\
\hline & during the process of writing. & 23 & 32 & 3 & 6 & 1 & \\
\hline \multirow[t]{2}{*}{33} & Teachers should dramatize all possible & $40.0 \%$ & $49.2 \%$ & $6.2 \%$ & $3.1 \%$ & $1.5 \%$ & 2 \\
\hline & $\begin{array}{l}\text { situations needed for an authentic act of } \\
\text { writing. }\end{array}$ & 26 & 32 & 4 & 2 & 1 & \\
\hline
\end{tabular}

Data analysis confirms that the environment in which writing is performed in most of the Sudanese universities did not enable the students to recognize the sort of language functions they were likely to express in real life communication. This means that a conducive environment should be the necessary first step to be taken should writing skill be promoted among university students in Sudan. Accordingly, peer reviewing, teacher feedback, authentic materials should be given more weight in future remedial syllabuses.

\subsection{Teachers' Feedback}

The role of feedback in developing students' writing capacities is shown in table 7.

Table 7: Teachers' Appraisal of the Role of Feedback in Promoting Students' Writing Quality

\begin{tabular}{|c|c|c|c|c|c|c|c|}
\hline No & Item & $\begin{array}{l}\text { Strongly } \\
\text { agree }\end{array}$ & Agree & No opinion & Disagree & $\begin{array}{l}\text { Strongly } \\
\text { disagree }\end{array}$ & Median \\
\hline \multirow[t]{2}{*}{34} & $\begin{array}{l}\text { The absence of the instructive and } \\
\text { supportive teacher's comments is one of the }\end{array}$ & $49.2 \%$ & $46.2 \%$ & $1.5 \%$ & $3.1 \%$ & . & 2 \\
\hline & $\begin{array}{l}\text { factors that affect students writing } \\
\text { negatively. }\end{array}$ & 32 & 30 & 1 & 2 & . & \\
\hline \multirow[t]{2}{*}{35} & $\begin{array}{l}\text { The feedback provided for the students } \\
\text { should focus on idea development, clarity }\end{array}$ & $29.2 \%$ & $49.2 \%$ & $1.5 \%$ & $20.0 \%$ & . & 2 \\
\hline & and coherence rather than grammar. & 19 & 32 & 1 & 2 & . & \\
\hline \multirow[t]{2}{*}{36} & $\begin{array}{l}\text { The methods and purpose of evaluators and } \\
\text { evaluation procedures negatively affect the }\end{array}$ & $20.0 \%$ & $50.8 \%$ & $6.2 \%$ & $21.5 \%$ & $1.5 \%$ & 2 \\
\hline & $\begin{array}{l}\text { students' written } \quad \text { communicative } \\
\text { competence. }\end{array}$ & 13 & 33 & 4 & 14 & 1 & \\
\hline \multirow[t]{2}{*}{37} & Teachers' negative comments demotivate & $47.7 \%$ & $33.8 \%$ & $7.7 \%$ & $7.7 \%$ & $3.1 \%$ & 2 \\
\hline & students and make them reluctant in their & 31 & 22 & 5 & 5 & 2 & \\
\hline
\end{tabular}


writing.

38 Teachers' comments distract students and lead them away from the purpose of writing a particular text in their voices.

Teachers' comments are worded in such a way that it is difficult for students to know exactly what they need to revise or correct.

Text-specific comment is such a factor that plays a very important role in developing students' written communicative competence.

41

Peer correction can positively influence students writing.

$\begin{array}{llllll}13.8 \% & 35.4 \% & 13.8 \% & 30.8 \% & 6.2 \% & 3 \\ 9 & 23 & 5 & 20 & 4 & \\ 15.4 \% & 40.0 \% & 15.4 \% & 27.7 \% & 1.5 \% & 2 \\ 10 & 26 & 10 & 18 & 1 & \\ 27.7 \% & 53.8 \% & 15.4 \% & 3.1 \% & . & 2 \\ 18 & 35 & 10 & 2 & & \\ & & & & & \\ 33.8 \% & 53.8 \% & 7.7 \% & 3.1 \% & 1.5 \% & 2 \\ 22 & 35 & 5 & 2 & 1 & \\ 60.0 \% & 33.8 \% & 4.6 \% & 1.5 \% & . & 1 \\ & & & & & \end{array}$

Statistical analysis shows that the majority of the target teachers confirmed the absence of instructive and supportive feedback on the students' writing regarding it as one of the factors that had negative impact on the development of the students' writing skills. The analysis also reveals that most of the teachers agreed that negative comments on students' writing demotivate the students and make them reluctant in writing. This supports the hypothesis that the sort of feedback Sudanese EFL learners receive on writing does not help them promote their writing competence.

\section{Conclusion}

The findings of the study suggest that the writing proficiency of the Sudanese university students was poor. The students lacked the basic skills required for communicative writing. This resulted in writing which was neither comprehensible nor informative. This indicates that students need to be acquainted with authentic written materials so that they can observe how writing is used by native speakers or other users of English. The findings also show that the students under study were unable to adopt effective writing strategies. Thus, writing instructors and syllabus designers should consider this issue when devising writing materials and activities. The study also highlighted the students' inability to produce connected written discourse. That is, they failed to use cohesive devices in writing, which caused them produce disconnected and incoherent written discourse. Syllabus designers and teachers should consider this problem in designing materials and teaching them to the students.

\section{References}

Abdallah, S. (2000). Investigating Sudanese EFL Learners' Written Discourse: The Case of the Fourth Year English Students in Some National Universities. Unpublished PhD Thesis, University of Khartoum.

Ahmed, F. (2010). An Analysis of Pertinacious Common Errors in the Writing Performance of EFL Learners in Sudan: A Case Study of University of Southern and Northern Kordufan States. Sudan.

Camps, A. (1994). L'ensenyament de la Composició Escrita. Barcelona: Barcanova: Graó. (Teaching Writing).

Deane, P., Odendahl, N., Quinlan, T., Fowles, M., Welsh, C., \& Bivens-Tatum, J. (2008). Cognitive Models of Writing: Writing Proficiency as a Complex Integrated Skill. ETS.

El Abed, W. (1991). The Effect of Selected Prewriting Activities on the Quantity and Quality of First Year Student Composition in Vocational Training Centres, Unpublished M.A. Thesis, Yarmouk University, Jordan

Elbow, P. (1998). Writing without Teachers. USA: Oxford University Press.

Fujieda, Y. (2006). A Brief Historical Sketch on Second Language Writing Studies: A Retrospective. Retrieved from http://www.kyoai.ac.jp/college/ronshuu/ No. 06/ fuieda.pdf

Hazel, S. (2005). The Writing Experiment: Strategies for Innovative Creative Writing. Allen \& Unwin.

Kellog, R. T. (2008). Training Writing Skills: A Cognitive Development Perspective. USA. 
Kress, J. (1993). The ESL Teacher's Book of Lists. USA.

Leki, I. (1992). Understanding ESL Writers: A Guide for Teachers. Portsmouth, NH: Boynton-Cook.

Matsuda, P. (1998). Situating ESL Writing in across-disciplinary Context. Written Composition and Communication, 50, 99-121. http://dx.doi.org/10.1177/0741088398015001004

Matsuda, P. (1999). Composition Studies and ESL Writing: a Disciplinary Division of Labour. College Composition and Communication, 50, 699-721. http://dx.doi.org/10.2307/358488

Matsuda, P. (2001). Reexamining Audiolingualism: on the Genesis of Reading and Writing in L2 Studies. In Belcher, D., Hirvela, A. (eds). Linking Literacies: Perspectives on Second Language Reading/Writing Connections. Ann Arbor, MI: University of Michigan Press; 84-105.

Matsuda, P. (2003). Second Language Writing in the Twentieth Century: A Situated History Perspective. In B Kroll (ed.) Exploring the Dynamics of Second Language writing (pp. 15-34). Cambridge: Cambridge University Press. http://dx.doi.org/10.1017/CBO9781139524810.004

Olateju, M. (2006). Cohesion in ESL Classroom Written Texts. Nordic Journal of African Studies, 15(3), 314-331.

Pishghadam, R., \& Ghanizadeh, A. (2006) On the Impact of Concept Mapping as Prewriting Activity on EFL Learners' Writing Ability. Iranian Journal of Applied Linguistics (IJAL), 9(2), 101-126.

Sasaki, M. (2000). Building on Empirically-based Model of EFL Learners' Writing Process. Japan.

Silva, T. (1997). On the Ethical Treatment of ESL Writing. TESOL Quarterly, 31(2), $359-363$. http://dx.doi.org/10.2307/3588052

Zhang, L., \& Vukelich, C. (1998). Prewriting Activities and Gender: Influences on the Writing Quality of Male and Female Students, ERIC Document Reproduction Service No. ED 42297. 